\title{
Nutritional Quality Evaluation of Seven Maize Varieties Grown in Ethiopia
}

\author{
Kidist Hailu Demeke \\ Department of Food Science and Nutrition Program, Ethiopian Institute of Agricultural Research, Head Office, Addis Ababa, Ethiopia
}

\section{Email address:}

Kidisth16@gmail.com

\section{To cite this article:}

Kidist Hailu Demeke. Nutritional Quality Evaluation of Seven Maize Varieties Grown in Ethiopia. Biochemistry and Molecular Biology. Vol. 3, No. 2, 2018, pp. 45-48. doi: 10.11648/j.bmb.20180302.11

Received: July 17, 2018; Accepted: August 9, 2018; Published: September 11, 2018

\begin{abstract}
Maize is a predominant staple crop in sub-saharan Africa. Ethiopia is among the major maize producers in Africa and ranked third next to South Africa and Nigeria. The per capita consumption of maize in Ethiopia is about $60 \mathrm{~kg}$ per annum. Maize is an important crop to many African countries contributing to a significant daily energy intake. In addition to serving as a critical source of macro- and micronutrients, maize is also a rich source of many phytochemicals including carotenoid. However, there is limited information about the nutritional content of the different maize varieties growing in Ethiopia. The aim of this study was to compare nutritional composition among six yellow maize varieties and one selected white maize variety cultivated in Ethiopia. Maize varieties were collected from Ethiopian Agricultural Research Institute, Melkasa and Bako center. Proximate and mineral composition analysis was carried out using AOAC method. Total carotenoid level was investigated by UV Spectrophotometer. Proximate composition of maize varieties revealed in the range of moisture content $(9.42-11.45 \%)$, total ash $(1.37-1.74 \%)$, crude fat $(5.13-7.22 \%)$, crude protein $(9.69-15.30 \%)$, crude fiber $(1.62-3.45 \%)$, carbohydrate (62.13 - 69.99\%) and Energy (365.93 to $385.82 \mathrm{kal} / 100 \mathrm{~g})$. The mineral content ranged for Fe, $\mathrm{Zn}$ and Ca was $2.34-3.73 \mathrm{mg} / 100 \mathrm{~g}, 2.31-2.93 \mathrm{mg} / 100 \mathrm{~g}$ and $31.25-48.1 \mathrm{mg} / 100 \mathrm{~g}$ respectively. The minimum total carotenoid in the yellow maize varieties was 11.43 (Melkassa 7) and the maximum was $27.62 \mu \mathrm{g} / \mathrm{g}$ (Melkassa 1q). No carotenoid was detected in the white maize variety $(\mathrm{BH} 660)$. There was significant difference $(\mathrm{P}<0.05)$ among maize varieties in total carotenoid. Yellow maize varieties contain high amount of carotenoid than white maize varieties. Promotion of yellow maize varieties is vital to enhance antioxidant intake that reduce risk of diseases such as cardiovascular and cancer without altering intake of other nutrients.
\end{abstract}

Keywords: Maize Varieties, Carotenoid, Proximate Composition and Minerals

\section{Introduction}

Maize or corn (Zea mays L.) is globally known as queen of cereals because of its highest genetic yield potential. Maize is the only food cereal crop that can be grown in diverse seasons, ecologies and uses. It is cultivated globally on more than 160 million hectare area across 166 countries [5]. Ethiopia is among the major maize producers in Africa and ranked third next to South Africa and Nigeria [10]. In Ethiopia the crop is widely cultivated at altitudes ranging from 1500-2200 meters above sea level of Western, Southwestern, and Southern parts of the country. Maize production takes significant share of cereals and grain in any production year Among cereals, maize ranked second to tef in area coverage $(21.7 \%$ for maize and $27.4 \%$ for tef), and first in total production ( $28.5 \%$ for maize and $19.9 \%$ for tef) and productivity [17].

The chemical composition of the maize kernel and its nutritional value give it a good position among the group of cereals in the "agrifood" category [12]. In Ethiopia, maize is a staple food in major maize producing areas. The per capita consumption of maize in Ethiopia is about $60 \mathrm{~kg}$ per annum [17]. Yellow maize, in addition to being dietary source of energy, lipids, protein, minerals and vitamins, it is a source of carotenoids $[2,6,16]$. Carotenoids are a diverse family of yellow-orange pigments generally categorized into two groups; carotenes (eg. $\beta$-carotene, $\alpha$-carotene) and xanthophylls (eg. $\beta$-cryptoxanthin, lutein, zeaxanthin). $\beta$ carotene, $\alpha$-carotene and $\beta$-cryptoxanthin are important precursors of vitamin A in humans [22]. Carotenoids are also 
potent antioxidants and important physiological modulators [24]. Food composition data is important in nutritional planning and provides data for epidemiological studies [3]. However, there is limited information about the nutritional content of the different maize varieties growing in Ethiopia. This study is designed to provide information on nutritional composition of one white and six yellow maize varieties grown in Ethiopia.

\section{Materials and Methods}

\subsection{Sample Collection and Sample Preparation}

Gibie Awash, CML165, BHQPY 545, CML 161 and BH were collected from Bako Agricultural Research center. Melkasa -1q, and Melkasa-7 were obtained from Melkasa Agricultural Research Center.

Sample preparation for analysis was done according to $(20,21)$.

\subsection{Determination of Proximate and Mineral Content}

Ash, moisture, fat, fiber, protein and mineral composition were carried out by [4] official method for nutrient analysis. The total carbohydrate was determined by differential method. The total energy of each sample was calculated in $\mathrm{kcal} / 100 \mathrm{~g}=\left(9 *\right.$ crude fat $+4 *$ crude protein $+4^{*}$ carbohydrate).

\subsection{Determination of Total Carotenoid}

Total carotenoid level was investigated by UV Spectrophotometer (Agilent 8653) by following the method [21]. Absorbance accuracy of UV Spectrophotometer for total Carotenoid Analysis was checked according to the procedure of the Association of Official Analytical Chemists as cited in [21]. Solution of $0.0400 \mathrm{~g} \mathrm{~K}_{2} \mathrm{CrO}_{4}$ per liter of 0.05 $\mathrm{N} \mathrm{KOH}$ was prepared and the absorbance was measured. $0.05 \mathrm{~N} \mathrm{KOH}$ solutions was used as blank. Each wave length absorbance was check two times. Expected absorbance and the mean of the two actual absorbance of each wave length were statistically compared using one sample t-test at $95 \%$ degree of confidence. Statistically, there was no significant difference between expected and actual value.

\subsection{Statistical Analysis}

Statistical Package for Social Sciences (SPSS) version 16.0 was used to analyze the data. Descriptive statistic mean, standard deviation (SD) and range were calculated from analysis and the data were expressed as mean $\pm \mathrm{SD}$. The mean were statistically compared by using one way ANOVA and LSD. Differences in means were considered significant at level of $\mathrm{P}<0.05$. All data were expressed in dry weight (DW).

\section{Result and Discussion}

\subsection{Proximate Composition}

Data regarding moisture, ash, protein, fat, fiber, carbohydrate and energy content of maize varieties are presented in table 1. There was a significant difference $(p<0.05)$ in moisture content among maize varieties except between CML 165 and Melkassa-7. The mean values obtained for moisture contents of maize varieties ranged from 9.42 (Melkasa 1q) to $11.45 \%(\mathrm{BH} 660)$ were in agreement with the range of moisture content of 5 maize varieties found by [14] which was between 8.96 and 12.45 . On the other hand this study finding was not in agreement with the result reported by [9] 4.3-6.7\% of twelve maize genotype.

Ash content in a food substance indicates inorganic remains after the organic matter has been burnt away and provides an estimate of the total mineral content of a food. There was significant difference $(\mathrm{P}<0.05)$ among maize varieties in total ash content except among (CML 165, Melkasa-7, Gibie Awash) and (CML 165, BH 660). The seven maize varieties total ash content ranged from $1.40(\mathrm{BH}$ 660 ) to.74\% (BHQMY 545) was higher than the range of total ash contents which were reported by [23] for ten maize varieties grown in Pakistan and [14] for five maize varieties. However, the range was in agreement with the range reported by [13] for three maize varieties.

Proteins serve as indispensable constituents of every living cell [24]. There was significant difference $(\mathrm{P}<0.05)$ among maize varieties. Crude protein content of maize varieties ranged from 9.69\% (CML 165) to $15.30 \%$ (BHQMY 545) was higher than the range which was reported by [14] for 5 maize varieties. On the other hand the present study range of crude protein contents were within the range reported by [9] for twelve genotype 11.3 to $16.9 \%$ and [23] for 10 varieties 7.7 to $14.6 \%$ but the crude protein content of $15.30 \%$ (BHQMY 545) was slightly higher than the range reported by [23].

Fat is the most concentrated source of energy that supplies $9 \mathrm{kcal} / \mathrm{g}$ [24]. Crude Fat content in maize varieties were significantly differ $(\mathrm{P}<0.05)$ except among $\mathrm{CML} 161$, Melkasa7 and $\mathrm{BH}$ 660. The seven maize varieties crude fat content ranged from 4.98 (Melkasa-7) to $7.22 \%$ (Melkasa1q) that was in agreement with the range reported by [23] for ten varieties and [7] for 109 varieties but higher than the range reported by [14] for 5 varieties.

Fiber has been postulated to have beneficial effects on diabetes, atherosclerosis, cancer, and appendicitis and prevention of duodenal ulcer formation and varicose veins [24]. Crude fiber content of maize varieties ranged from 1.62 (Melkasa 1q) to $3.46 \%$ (BHQMY 545) which was in agreement with reported by [13, 14, 23] except BHQMY $545(3.45 \%)$ but it was in between the result reported by [1].

Carbohydrates are a source of energy for the body and offer a wide range of rheological and other functional properties to foods [24]. Percent carbohydrate content of seven maize varieties were found in the range 62.13 (BHQMY 545) to $69.99 \%$ (CML 165) that was not within the range reported by [23] for ten maize varieties whereas in agreement with the findings of [13].

Maize is important source of energy [15]. Energy content of seven maize varieties were found in the range 365.93 
(CML 161) to $385.82 \mathrm{kal} / 100 \mathrm{~g}$ (Melkasa 1q) as indicated in Table 1 that fall within the range reported by [23] for ten maize varieties. There was significant difference $(\mathrm{P}<0.05)$ among varieties. There was no significant difference ( $\mathrm{P}>0.05)$ among varieties BHQMY 545, Melkasa 7, Gibie Awash and $\mathrm{BH} 660$.

Table 1. Proximate values in maize varieties grown in Ethiopia.

\begin{tabular}{|c|c|c|c|c|c|c|c|}
\hline Varieties & $\begin{array}{l}\text { Moisture } \\
(\%)\end{array}$ & $\begin{array}{l}\text { Total Ash (\% } \\
\text { DW) }\end{array}$ & $\begin{array}{l}\text { Crude Protein } \\
(\% \text { DW) }\end{array}$ & $\begin{array}{l}\text { Crude Fat (\% } \\
\text { DW) }\end{array}$ & $\begin{array}{l}\text { Crude Fiber } \\
(\% \text { DW) }\end{array}$ & $\begin{array}{l}\text { Carboh ydrate (\% } \\
\text { DW) }\end{array}$ & $\begin{array}{l}\text { Energy } \\
\text { kal/100g (DW) }\end{array}$ \\
\hline CML 161 & $\neq 11.31 \pm 0.01^{\mathrm{b}}$ & $1.40 \pm 0.02^{\mathrm{e}}$ & $12.03 \pm 0.12^{\mathrm{d}}$ & $5.13 \pm 0.04^{\mathrm{d}}$ & $2.22 \pm 0.02^{\mathrm{c}}$ & $67.91 \pm 0.32^{c}$ & $365.93 \pm 1.93^{\mathrm{e}}$ \\
\hline Melkasa-1q & $9.42 \pm 0.01^{\mathrm{f}}$ & $1.53 \pm 0.01^{\mathrm{d}}$ & $13.11 \pm 0.13^{\mathrm{b}}$ & $7.22 \pm 0.01^{\mathrm{a}}$ & $1.62 \pm 0.02^{\mathrm{e}}$ & $67.10 \pm 0.55^{\mathrm{c}}$ & $385.82 \pm 1.83^{\mathrm{a}}$ \\
\hline BHQMY 545 & $10.62 \pm 0.01^{\mathrm{d}}$ & $1.74 \pm 0.03^{\mathrm{a}}$ & $15.30 \pm 0.02^{\mathrm{a}}$ & $6.71 \pm 0.01^{\mathrm{b}}$ & $3.45 \pm 0.08^{\mathrm{a}}$ & $62.13 \pm 0.47^{\mathrm{d}}$ & $370.27 \pm 2.09^{\mathrm{cd}}$ \\
\hline CML 165 & $9.93 \pm 0.02^{\mathrm{e}}$ & $1.62 \pm 0.02^{\mathrm{cd}}$ & $9.69 \pm 0.06^{\mathrm{e}}$ & $6.14 \pm 0.03^{c}$ & $2.63 \pm 0.03^{b}$ & $69.99 \pm 0.34^{\mathrm{a}}$ & $373.98 \pm 2.59^{b}$ \\
\hline Melkassa-7 & $9.91 \pm 0.01^{\mathrm{e}}$ & $1.63 \pm 0.04^{\mathrm{c}}$ & $11.92 \pm 0.13^{\mathrm{d}}$ & $4.98 \pm 0.02^{\mathrm{d}}$ & $2.46 \pm 0.16^{\mathrm{b}}$ & $69.10 \pm 0.16^{\mathrm{b}}$ & $368.90 \pm 1.84^{\mathrm{de}}$ \\
\hline Gibie Awash & $11.01 \pm 0.06^{\mathrm{c}}$ & $1.46 \pm 0.02^{\mathrm{d}}$ & $10.27 \pm 0.18^{\mathrm{e}}$ & $6.05 \pm 0.05^{\mathrm{c}}$ & $2.26 \pm 0.02^{c}$ & $68.95 \pm 0.25^{b}$ & $371.33 \pm 1.56^{\mathrm{bc}}$ \\
\hline BH 660 & $11.45 \pm 0.02^{\mathrm{a}}$ & $1.37 \pm 0.03^{\mathrm{e}}$ & $12.32 \pm 0.11^{\mathrm{c}}$ & $5.33 \pm 0.03^{\mathrm{d}}$ & $1.82 \pm 0.04^{\mathrm{d}}$ & $67.71 \pm 0.52^{\mathrm{c}}$ & $368.09 \pm 1.98^{\mathrm{cd}}$ \\
\hline
\end{tabular}

Values within the same column followed by different superscripts are significantly different $(\mathrm{P}<0.05)$.

₹ such values are the mean $\pm \mathrm{SD}$ of triplicate

\subsection{Iron, Zinc and Calcium Content}

A number of minerals are essential for body functions. They are classified as macro minerals or micro minerals (trace elements) depend on their dietary requirement. Calcium is part of macro minerals whereas iron and zinc are micro minerals [24]. Three Minerals content of seven maize varieties is given in Table 2. The result showed Fe (2.34 to $3.70 \mathrm{mg} / 100 \mathrm{~g}), \mathrm{Zn}$ (2.31 to $2.93 \mathrm{mg} / 100 \mathrm{~g})$ and $\mathrm{Ca}(21.98$ to $48.10 \mathrm{mg} / 100 \mathrm{~g})$. (23) reported higher content of these three minerals in 10 maize varieties than present study while $\mathrm{Zn}$ and $\mathrm{Fe}$ were in agreement with the report of [19] in 22 varieties and [7] in 109 varieties. $\mathrm{Fe}$ and $\mathrm{Ca}$ content was significantly differ $(\mathrm{P}<0.05)$ among maize varieties but not significant $\mathrm{P}>0.05$ between CML 161 and CML 165 regarding Fe content.

The variability in protein, fats, ash, crude fiber, moisture, carbohydrates and mineral content of maize varieties may be due to genetics and environmental factors $(18,23)$.

\subsection{Total Carotenoid}

The present study as indicated in Table 2 revealed difference among the maize varieties in total carotenoid level. It was below detection limit in white maize variety ( $\mathrm{BH} 660$ ). Highest total carotenoid $(27.62 \mu \mathrm{g} / \mathrm{g})$ content was found in the Melkasa 1q yellow maize variety and the lowest 11.43 $\mu \mathrm{g} / \mathrm{g}$ for Melkasa7. Statistically there was significant difference $(\mathrm{P}<0.05)$ among yellow maize varieties in total carotenoid. The varied results of yellow maize varieties were in between the tested maize varieties obtained by [22] ranged 5.58 to $63.9 \mu \mathrm{g} / \mathrm{g}$ and [11] ranged 9.69 to $13 \mu \mathrm{g} / \mathrm{g}$. But total carotenoid result of this study was not in agreement with the result that was reported by [7] in maize hybrid total carotenoid ranged 143 to $278 \mu \mathrm{g} / \mathrm{g}$. Yellow maize has the highest phenotypic variability in carotenoids content [21]. Carotenoids are potent antioxidants and important physiological modulators [24]. Yellow maize is basically comparable to white maize in nutritional composition except for its grain color due to the presence of carotenoids [8].

Table 2. Fe, Zn, Ca and total carotenoid content of maize varieties.

\begin{tabular}{llllll}
\hline Varieties & Kernel color & Fe (mg/100g DW) & Zn (mg/100g DW) & Ca (mg/100g DW) & Total Carotenoid $\boldsymbol{\mu g} / \mathbf{g}(\mathbf{D W})$ \\
\hline CML 161 & Yellow & $\ddagger 3.70 \pm 0.04^{\mathrm{a}}$ & $2.50 \pm 0.05^{\mathrm{b}}$ & $34.39 \pm 0.04^{\mathrm{d}}$ \\
Mellkassa-1q & Yellow & $2.34 \pm 0.01^{\mathrm{e}}$ & $2.46 \pm 0.03^{\mathrm{b}}$ & $30.86 \pm 0.09^{\mathrm{f}}$ \\
BHQMY 545 & Yellow & $2.46 \pm 0.02^{\mathrm{d}}$ & $2.48 \pm 0.03^{\mathrm{b}}$ & $34.92 \pm 0.02^{\mathrm{c}}$ & $27.62 \pm 0.24^{\mathrm{a}}$ \\
CML 165 & Yellow & $3.73 \pm 0.04^{\mathrm{a}}$ & $2.31 \pm 0.08^{\mathrm{c}}$ & $21.98 \pm 0.05^{\mathrm{g}}$ \\
Mellkassa-7 & Yellow & $3.27 \pm 0.07^{\mathrm{b}}$ & $2.93 \pm 0.04^{\mathrm{a}}$ & $36.32 \pm 0.09^{\mathrm{b}}$ \\
Gibie Awash & Yellow & $3.18 \pm 0.05^{\mathrm{c}}$ & $2.92 \pm 0.06^{\mathrm{a}}$ & $19.01 \pm 0.13^{\mathrm{d}}$ \\
BH 660 & White & $2.39 \pm 0.01^{\mathrm{e}}$ & $2.52 \pm 0.07^{\mathrm{b}}$ & $48.10 \pm 0.06^{\mathrm{a}}$ & $31.25 \pm 0.08^{\mathrm{e}}$ \\
\hline
\end{tabular}

Values within the same column followed by different superscripts are significantly different $(\mathrm{P}<0.05)$.

₹ such values are the mean $\pm \mathrm{SD}$ of triplicate

ND is not detected.

\section{Conclusion}

The data reveal difference in nutritional composition of seven maize varieties that may be due to environmental and genetics factors. Yellow maize variety contains high amount of total carotenoids than white variety. In addition, its other nutrients were comparable to white maize variety. Promotion of yellow maize varieties in Ethiopia is vital to enhance antioxidant intake that reduce risk of diseases such as cardiovascular and cancer.

\section{Acknowledgements}

I would like to express my sincere gratitude to Addis Ababa University Food Science and Nutrition department, Ethiopian Conformity Assessment Enterprise, chemical testing, laboratory staff and Dr Tarekegn Birhanu for help me during laboratory analysis and Ethiopian Institute of 
Agricultural Research for providing samples.

\section{References}

[1] Abdo E. M., Barbary O. M. and Shaltout O. E (2013). Chemical analysis of BT corn "Mon810: Ajeeb-YG" and its counterpart non-Bt corn "Ajeeb". IOSR Journal of Applied Chemistry, 4; 55-60.

[2] Adom, K. K. and Liu R. H. (2002). Antioxidant activity of grains. Journal of Agriculture and Food Chemistry, 50; 6182 6187.

[3] Ali M., Ali W., Ahmed S., Ullah I.,(2008). Mineral composition quality and physic-chemical parameters of the local Tallow Pakistan. Pakistan Journal of nutrition, 7; 717720.

[4] AOAC (2005), American Official Chemist Method, Washington, USA.

[5] Bhupender K. et al (2012) Maize biology: An introduction. Indian Council of Agricultural Research (ICAR), Technical bulletin.

[6] Dewanto. V., Wu, X. Z., Liu, R. H. (2002) Processed sweet corn has higher antioxidant activity. Journal of Agriculture Food Chemistry, 50; 4959- 4964.

[7] Dixon B. M. (2000) Genetic variation in total carotene, iron, and zinc contents of maize and cassava genotypes, Food and Nutrition Bulletin, 21; 419-422.

[8] Egesel, C. O., J. C. Wong R. J. Lambert, and T. Rocheford. (2003). Combining ability of maize inbreds for carotenoids and tocopherols. Crop Science, 43; 818-823.

[9] Fageer A. S. M, Tinay A. H. E (2004). Effect of genotype, malt pretreatment and cooking on in vitro protein digestibility and protein function of corn. Food chemistry, 84; 613-619.

[10] (FAO) Food and Agricultural Organization of the United Nations (2012), http://faostat3.fao.org.

[11] Fardet A., Rock E. and Remesy C. (2008). Is the in vitro antioxidant potential of whole-grain cereals and cereal products well reflected in vivo? Journal of Cereal Science, 48; 258-276.

[12] Hoopen T. and Maiga A. (2012). Maize production and processing. Cameroon.

[13] Ijabadeniyi, A. O. and Adebolu, T. T. (2005). The effect of processing methods on the nutritional properties of ogi produced from three maize varieties. Journal of Food Agriculture and Environment, 3; 108-109.
[14] Kumar U. and Kweera B. (2014). Comparative analysis of nutritional value and aflatoxin level of maize grain from different site of Rajasthan. International Journal of Scientific and Technology Research, 2; 333-335.

[15] McKevith B. (2004). Nutritional aspects of cereals. British Nutrition Foundation Nutrition Bulletin, 29; 111-142.

[16] Menkir A., White W. S., Maziya-Dixon B., Rocheford T., Weiping L., 2008. Carotenoid diversity in tropical adapted yellow maize inbred lines. Food chemistry, 109; 521-529.

[17] Mosisa W., Legesse W., BirhanuT., Girma D., Girum A., Wende A., Tolera K., Gezahegn B.(2011). Status and future direction of maize research and production in Ethiopia. Proceedings of the Third National Maize Workshop of Ethiopia, 18-20 April 2011 Addis Ababa, Ethiopia (pp. 17-23). Addis Ababa: EARO (Ethiopian Agricultural Research Organization) and CIMMYT (International and wheat Improvement Center).

[18] Ndukwe O. K., Edeoga H. O., Omosun G. (2015). Varietal differences in some nutritional composition of ten maize (Zea mays L.) varieties grown in Nigeria. International journal of academic research and reflection, 5; 1-11.

[19] Queiroz V. P., Guimaraes P. E., Queiroz L. R., Guedes E. D., Vasconclos V. D., Guimaraes L. J., Ribeiro P. E. and Schaffer R. E. (2011). Iron and zinc availability in maize line, 31; 577583.

[20] Rios A. R., Paes M. C., Cardoso W. S., Borem A., Teixeira F. (2014). Color of corn grains and carotenoid profile of importance for human health. American Journal of Plant Sciences, 5; 857-862.

[21] Rodriguez-Amaya D. R. and Kimura M. (2004). Harvestplus handbook for carotenoid analysis. HarvestPlus Technical Monograph, Washington, DC.

[22] Safawo T., Senthi N., Raveendran M., Vellaikumar S. Ganesan K. N., Nallarhambi G., Saranya S., Shobrana V. G., Abirami B. and Gowri E. V. (2010). Exploitation of natural variability in maize for $\beta$-Carotene content using HPLC and gene specific markers. Journal of Plant Breeding, 1; 548-555.

[23] Ullah I., Ali M. and Farooqi A. (2010). Chemical and nutritional properties of some maize (Zea mays L.) varieties grown in NWFP, Pakistan. Pakistan Journal of Nutrition 9; 1113-1117.

[24] Yeung D. L. and Laquatra I. (2003). Heinz Handbook of Nutrition. 9th Edition, H. J., Heinz Company. 